\title{
Bond between microwave cured repair and concrete substrate
}

\author{
Konstantinos Grigoriadis $\cdot$ P. S. Mangat $\cdot$ Shahriar Abubakri
}

Received: 29 February 2016/ Accepted: 20 December 2016/Published online: 19 January 2017

(C) The Author(s) 2017. This article is published with open access at Springerlink.com

\begin{abstract}
The bond strength between a concrete substrate and repair patch is critical to its durability. This paper investigates the effect of microwave curing the freshly applied repair, for $45 \mathrm{~min}$ at 132 Watts, on the 28 day bond strength between substrate concrete and different commercial repair materials. The repairs were applied at different ambient temperatures of 20 , 10,2 and $-5{ }^{\circ} \mathrm{C}$. Tensile split tests on repaired cube specimens were performed to determine the interfacial bond strength. The ability of microwave curing to prevent the detrimental effects of freezing at early age on the bond and compressive strength of repair patches is investigated. Experimental results show that microwave curing prevents loss of long term (28 day) repair/substrate bond strength of repair materials applied at freezing temperatures $\left(-5^{\circ} \mathrm{C}\right)$, relative to the repairs applied at higher temperatures $\left(2-20{ }^{\circ} \mathrm{C}\right)$, except one lightweight repair formulation. In comparison, the control samples (non-microwave cured) of repairs applied at $-5^{\circ} \mathrm{C}$ suffered severe loss of bond strength and compressive strength due to early age freezing. In addition, no adverse effects on the bond strength and a small reduction of $6.75 \%$ in the 28 day compressive strength are observed in the early age microwave cured repairs applied at ambient
\end{abstract}

K. Grigoriadis · P. S. Mangat $(\bowtie) \cdot S$. Abubakri Centre for Infrastructure Management, Materials and Engineering Research Institute, Sheffield Hallam University, Sheffield S1 1WB, UK

e-mail: p.s.mangat@shu.ac.uk temperatures of $2-20{ }^{\circ} \mathrm{C}$. The repair/substrate bond strength is independent of the compressive strength of the repair material at all temperatures of repair application. Microwave curing can accelerate the concrete repair process and facilitate construction activity in cold weather.

Keywords Concrete $\cdot$ Patch repair - Microwave curing $\cdot$ Bond strength $\cdot$ Tensile split test
Abbreviations
$L \quad$ Height of the composite cube ( $\mathrm{mm}$ )
$P \quad$ Applied load during the tensile splitting test
(N)
SD Standard deviation
$\sigma_{x \max }$ Maximum horizontal tensile stress at the centre of the composite cube (MPa)
$\sigma_{y \max }$ Maximum vertical compressive stress at the centre of the composite cube (MPa)
$\Delta T \quad$ Temperature differential $\left({ }^{\circ} \mathrm{C}\right)$

\section{Introduction}

Most repairs to concrete structures are applied as patch repairs. They are classified as non-structural or cosmetic repairs when load carrying capacity is not required and structural repairs when they carry load [1]. Emmons [2] provides a detailed description of the 
various stages involved in the execution of a patch repair. The mechanical properties considered during selection of repair materials for structural patch repairs include compressive, tensile and flexural strength. These should be compatible with the substrate concrete in order to provide efficient structural interaction [2]. In addition, the substrate/repair interfacial bond strength is critically important for the durability of a patch repair and its load sharing capability with the substrate. Bond failure at the interface is the cause of most patch repair failures. The Concrete Society Technical Report 38 (CSTR 38) [3] recommends a minimum bond strength of $0.8 \mathrm{MPa}$, based on the pull-off test.

High early age strength development is often required of repairs to structures such as airport runways, bridge decks and car parks to minimise delays, disruption and financial loss to the users and owners of such structures. Accelerated curing, either by applying heat or using special repair formulations, is required since cementitious materials, under normal ambient curing, can take over $24 \mathrm{~h}$ to harden and several days to develop sufficient strength [4]. The heat curing methods used in current practice, such as open flame heaters, are unsuitable for modern construction. Cold weather repair application is another example in which high early age strength is required to avoid the detrimental effects of freezing on long-term compressive strength and durability. If concrete is subjected to freezing immediately after mixing, setting will be suspended. When, at a later age, thawing occurs, the concrete will be able to set and harden without significant loss of strength provided revibration takes place immediately after thawing [5]. If concrete is allowed to first set without achieving sufficient strength and then freeze, its later age strength will be reduced due to damage caused by expansion during formation of ice. If, on the other hand, concrete is able to achieve sufficient strength (approximately 3.5 MPa [6]), it will be able to resist the damage caused by one cycle of freezing and thawing. However, in practice it is difficult to determine when concrete has achieved sufficient strength prior to freezing since its setting and hardening are considerably influenced by temperature [5].

The effect of thermal curing on the repair-substrate bond strength is also of particular concern as this is the weakest link in the repair patch system where failure can initiate in the long term. Thermal curing, especially when it is non-uniform, results in some reduction in long term strength [7].

Microwave curing is ideally suited to provide accelerated strength development of repair patches in both normal and cold weather conditions. It provides relatively uniform heating from within a repair patch without temperature gradients. The temperature can be controlled to provide optimum curing and minimise deleterious effects on hydration products and microcracking. It reduces setting time and increases early age strength of cement based repair materials [4, 8-17] thereby preventing disruption and delays by shortening the required curing time of patch repairs in concrete structures such as bridge decks and airport runways.

The durability of patch repair systems is a serious concern as most structure owners are dissatisfied with repairs within 10 years of application [18, 19]. The bond between the repair patch and the substrate is usually the weakest link, which is compromised. The effect of aggressive environment conditions, such as freezing weather at early age, and the use of uncontrolled thermal curing with traditional methods on site can be damaging to the bond strength. This paper is part of the research programme which aims to develop the potential of early age microwave curing for accelerating the concrete repair process in all weather conditions, preventing disruption to construction activity in cold weather and provide durable repair. It investigates the effect of up to $45 \mathrm{~min}$ of microwave curing fresh patch repair on its long term (28 days) interfacial bond strength when the repair is applied at different ambient temperatures. The patch repair was applied under ambient temperatures of $-5,2,10$ and $20{ }^{\circ} \mathrm{C}$. Each ambient temperature was maintained for $24 \mathrm{~h}$ from the time of mixing the repair material to allow sufficient time for its full effect on the repair during its early period of strength development when it is most vulnerable to durability attack. After $24 \mathrm{~h}$ the repaired concrete specimens were cured in water at $20{ }^{\circ} \mathrm{C}$, until 28 days age. The 28 day compressive strength of the repair patch was also determined under these exposure conditions. There is no published data available on the effect of microwave curing on the bond strength of patch repairs applied under different ambient temperatures.

This paper is part of a larger research project funded by the European Commission on microwave curing of patch repair and to develop a prototype system for 
in situ curing of concrete patch repairs (FP7 MCure project). The prototype has been successfully tested on $1 \mathrm{~m} \times 1 \mathrm{~m}$ patch repairs and is being taken to the next stage of commercial development.

\section{Experimental procedure}

\subsection{Test programme}

The effect of microwave curing on the bond strength between concrete substrates and various commercial repair materials was determined in a laboratory investigation. Halves of $100 \times 100 \times 100 \mathrm{~mm}$ substrate concrete cubes were placed in moulds and the top half of the mould was filled with a repair material to form a $100 \mathrm{~mm}$ composite cube. The composite cube, therefore, was composed of equal halves of substrate and repair material. The test programme is given in Table 1. The half-cube "repairs" were applied at ambient temperatures $-5,2,10$ and $20{ }^{\circ} \mathrm{C}$ with four repair materials. The compressive strength of the substrate cubes ranged between 48.5 and $58 \mathrm{MPa}$.

\subsection{Repair materials}

Three proprietary repair materials and a standard mortar composition were used in the investigation. Properties of the repair materials are given in Table 2. Material 1 was a rapid hardening, shrinkage compensated material containing fly ash. Materials 2 and 3 were polymer modified cement mortars, shrinkage compensated and fibre reinforced. They represented a low and high density material respectively. Material 4 was a standard 1:2 (by weight) mortar composition with w/c of 0.5. The constituents were CEM II/A-L 32.5 N Portland-limestone cement [20] and coarse sharp sand $(50 \%$ passing $600 \mu \mathrm{m})$.

\subsection{Microwave curing and temperature conditioning equipment}

A Sharp Model R-2370 commercial microwave oven of 1320 Watts capacity, $2.45 \mathrm{GHz}$ frequency was used for curing the repaired specimens. The power was controlled in $10 \%$ increments. The microwave oven was calibrated according to ASTM F1317 [21] and BS

Table 1 Details of tests

\begin{tabular}{|c|c|c|c|c|c|c|}
\hline \multirow[t]{2}{*}{ Series } & \multirow[t]{2}{*}{$\begin{array}{l}\text { Number of substrate } \\
\text { cubes }\end{array}$} & \multirow[t]{2}{*}{$\begin{array}{l}\text { Substrate strength } \\
(\mathrm{MPa})^{\mathrm{a}}\end{array}$} & \multirow[t]{2}{*}{$\begin{array}{l}\text { Repair temperature } \\
\left({ }^{\circ} \mathrm{C}\right)\end{array}$} & \multirow[t]{2}{*}{$\begin{array}{l}\text { Repair } \\
\text { material }\end{array}$} & \multicolumn{2}{|c|}{$\begin{array}{l}\text { Number of composite (repaired) } \\
\text { cubes }\end{array}$} \\
\hline & & & & & $\begin{array}{l}\text { Normally } \\
\text { cured }\end{array}$ & $\begin{array}{l}\text { Microwave } \\
\text { cured }\end{array}$ \\
\hline \multirow[t]{4}{*}{1} & 4 & 48.5 & 20 & Material 1 & 4 & 4 \\
\hline & 4 & 48.5 & 20 & Material 2 & 4 & 4 \\
\hline & 4 & 48.5 & 20 & Material 3 & 4 & 4 \\
\hline & 4 & 49.5 & 20 & Material 4 & 4 & 4 \\
\hline \multirow[t]{4}{*}{2} & 4 & 49.5 & 10 & Material 1 & 4 & 4 \\
\hline & 4 & 49.5 & 10 & Material 2 & 4 & 4 \\
\hline & 4 & 49.5 & 10 & Material 3 & 4 & 4 \\
\hline & 4 & 49.5 & 10 & Material 4 & 4 & 4 \\
\hline \multirow[t]{4}{*}{3} & 4 & 49.5 & 2 & Material 1 & 4 & 4 \\
\hline & 4 & 52.0 & 2 & Material 2 & 4 & 4 \\
\hline & 4 & 52.0 & 2 & Material 3 & 4 & 4 \\
\hline & 4 & 52.0 & 2 & Material 4 & 4 & 4 \\
\hline \multirow[t]{4}{*}{4} & 4 & 58.0 & -5 & Material 1 & 4 & 4 \\
\hline & 4 & 58.0 & -5 & Material 2 & 4 & 4 \\
\hline & 4 & 48.5 & -5 & Material 3 & 4 & 4 \\
\hline & 4 & 48.5 & -5 & Material 4 & 4 & 4 \\
\hline
\end{tabular}

a 28 days compressive strength 
Table 2 Properties of the repair materials

${ }^{\text {a }} W / P$ water/powder ratio (water/cement ratio for Material 4)

b Manufacturer's compressive strength data

\begin{tabular}{|c|c|c|c|c|}
\hline \multirow[t]{2}{*}{ Properties } & \multicolumn{4}{|c|}{ Repair material } \\
\hline & Material 1 & Material 2 & Material 3 & Material 4 \\
\hline $\mathrm{W} / \mathrm{P}^{\mathrm{a}}$ & 0.13 & 0.14 & 0.11 & 0.50 \\
\hline 28 Days strength $(\mathrm{MPa})^{\mathrm{b}}$ & 65.0 & 42.0 & $65-70$ & 42.0 \\
\hline Adhesive bond (MPa) & $\geq 1.5$ & Class $\mathrm{R} 4 \geq 2.0$ & - & - \\
\hline Elastic modulus (GPa) & $\geq 15$ & 18.2 & - & $>20$ \\
\hline Density of mix $\left(\mathrm{kg} / \mathrm{m}^{3}\right)$ & 2260 & 1730 & 2280 & 2200 \\
\hline
\end{tabular}

EN 60705 [22]. All specimens were cured at 132 Watts.

A Sanyo Model MTH 4400 PR ATMOS environmental chamber (temperature range from -20 to $105^{\circ} \mathrm{C}$ ) was used to condition the concrete substrate specimens, repair material constituents and the composite cubes, before and for $24 \mathrm{~h}$ after repair, to ambient temperature of either $20,10,2$ or $-5{ }^{\circ} \mathrm{C}$ (Series 1, 2, 3 or 4, respectively, Table 1).

\subsection{Details of specimens, mixing and microwave curing}

\subsubsection{Introduction}

The main parameters of the substrate which affect repair performance are its stiffness (elastic modulus), shrinkage and creep relative to the repair patch. High shrinkage of the substrate reduces the differential shrinkage of the repair patch and prevents shrinkage cracking. Similarly low stiffness of repair patches relative to the substrate is recommended in practice to prevent cracking [2]. In practice a substrate can be decades old when a repair patch is applied. Its creep and shrinkage have stabilised by this time and maximum elastic modulus has been developed. The high stiffness, shrinkage free substrate aids crack prevention in a new repair patch by reducing tensile stresses at the repair interface due to differential shrinkage. The decades old substrate has been simulated in the research reported in this paper by preparing a high strength concrete substrate $(w / c=0.4$, strength and elastic modulus approximately 58.0 MPa and 36 GPa respectively) which consequently has a higher elastic modulus than all the repair materials investigated. The shrinkage of the substrate is stabilised by curing the specimens in water for 28 days before the application of repair and subsequently for 27 days when bond tests were conducted. Creep effects were also absent since negligible stress was induced at the repair interface.

The research reported in this paper, however, is concerned with the bond strength between the repair patch and the substrate. Bond strength is also of fundamental importance in the performance of repair. This property was investigated by isolating other effects such as shrinkage.

\subsubsection{Substrate specimen preparation}

Cube specimens of high strength substrate concrete (48.5-58 MPa, Table 1) were made using CEMII/A-L 32.5 N Portland-limestone cement [20], coarse sharp sand (50\% passing a $600 \mu \mathrm{m}$ sieve) and uncrushed river gravel (maximum size of $10 \mathrm{~mm}$ ) with w/c of 0.4 . The mix was designed according to the BRE guide [23]. Four $100 \mathrm{~mm}$ size cubes per mix (Table 1) were cast in steel moulds and compacted on a vibrating table. Special care was taken to keep the trowelled face of the cubes smooth and level. The compacted specimens were covered with plastic sheets and kept in a laboratory environment $\left(20^{\circ} \mathrm{C}, 60 \% \mathrm{RH}\right)$ for $24 \mathrm{~h}$ after mixing. The specimens were then de-moulded and cured in water at $20{ }^{\circ} \mathrm{C}$ for 27 days. At 28 days age the $100 \times 100 \times 100 \mathrm{~mm}$ substrate cubes $(4$ per mix, Table 1) were cut in two halves using a masonry saw. The orientation of the cutting plane was parallel to the trowelled face of the cubes. The cut faces were then grit blasted for $1 \mathrm{~min}$.

The eight sawn and grit blasted substrate cube halves per mix (Table 1) $(100 \times 100 \times 50 \mathrm{~mm}$ prisms) were placed in a water tank (temperature $20{ }^{\circ} \mathrm{C}$ ) until the application of the repair. Before the application of repair to the half-cube of substrate, all the components were conditioned to the ambient "repair temperatures" given in Table 1, as described in Sect. 2.4.3. 


\subsubsection{Temperature conditioning and composite cube preparation}

The constituents of each repair material mix and the substrate concrete halves $(100 \times 100 \times 50 \mathrm{~mm}$ prisms) were kept in the environmental chamber overnight prior to mixing in the laboratory. The chamber was set at $20,10,2$ and $-5{ }^{\circ} \mathrm{C}$ respectively to regulate the temperature of the repair mix constituents and the substrate cube-halves to the "repair temperatures" given in Table 1. The temperature conditioned materials were transferred to the laboratory $\left(20^{\circ} \mathrm{C}\right.$, $60 \% \mathrm{RH})$, mixed and composite cubes of the repaired substrate were cast immediately. At the time of casting the repair, the saturated and temperature regulated substrate halves $(100 \times 100 \times 50 \mathrm{~mm}$ prisms $)$ were placed inside polystyrene moulds with their sawn, grit blasted and saturated surface dry face upwards. The top halves of the cubes were then "repaired" by filling the moulds with each of the four "temperature conditioned" repair mortars and compacted on a vibrating table. The "repaired" cubes were then covered and transferred back to the environmental chamber to maintain their overnight regulated temperature. Half an hour after the repair application, 50\% of the repaired specimens (4 composite cubes per repair material) were removed from the environmental chamber and microwave cured. Microwave curing was applied for $45 \mathrm{~min}$ at 132 Watts to achieve curing temperatures within the optimum range of $40-45^{\circ} \mathrm{C}$, as determined by Mangat et al. [24, 25]. Immediately after microwave curing, the composite cubes were covered and returned to the environmental chamber where the control samples of composite cubes made with each repair material had remained since the application of repair. The environmental chamber temperature remained pre-set at $20,10,2$ and $-5{ }^{\circ} \mathrm{C}$, respectively for Series 1-4 tests.

All the composite cubes (both normally and microwave cured) were removed from the environmental chamber after $24 \mathrm{~h}$, de-moulded and cured in water at $20{ }^{\circ} \mathrm{C}$ for 27 days. Tensile split tests were performed on the composite cubes at 28 days age of the repair patch (the substrate was 56 days old).

In real practice, for any given ambient temperature and substrate volume, the required microwave power will be applied to a freshly applied repair patch to reach the target curing temperature in a given time. The whole repair patch including the interface zone of the substrate will get heated. During microwave heating, the repair patch will develop some strength which may subsequently enable it to resist frost attack under sub-zero temperature exposure.

This situation has been simulated in the laboratory investigation albeit in reality the in situ substrate/repair patch volume ratio may be much greater than the ratio of unity used in the reported tests. Subsequent to $45 \mathrm{~min}$ of microwave curing to a temperature of about $40{ }^{\circ} \mathrm{C}$, the specimens were transferred to the environmental chamber for $24 \mathrm{~h}$. The chamber was set at the pre-determined ambient temperature of 20 to $-5^{\circ} \mathrm{C}$ (Table 1). Cooling of the specimens occurred mainly from the top surface plus loss of heat to the substrate. However, the fairly small volume of the microwave cured repair patches $(100 \times 100 \times 50 \mathrm{~mm})$ in the laboratory specimens cooled down fairly rapidly to the ambient temperature of the environmental chamber. Consequently, during the $24 \mathrm{~h}$ post-microwave curing period, the specimens were predominantly at the ambient temperature of the chamber. The polystyrene mould faces provided greater insulation than potential insulation from repaired concrete substrates on site and the effect of different substrate/repair volume ratios on the rate of cooling of the microwave cured repair is likely to be different. However, the effect of fairly rapid cooling after microwave curing has been effectively simulated in the tests reported in the paper. The extrapolation of the results to the field will primarily be concerned with the microwave power required on site to produce the same target temperature of curing achieved in the laboratory. This is discussed in Sect. 3.7.

\subsection{Testing}

\subsubsection{Tensile split test}

Bond strength was determined by the tensile split test on the composite cubes according to BS EN 12390-6 [26], as shown in Fig. 1. The load $(P)$ applied on two diametrically opposite generatrices produces vertical compressive and horizontal tensile stresses at the centre of the cube as follows [26-28]:

$$
\begin{gathered}
\sigma_{y \max }=\frac{6 P}{\pi L^{2}} \\
\sigma_{x \max }=\frac{2 P}{\pi L^{2}}
\end{gathered}
$$




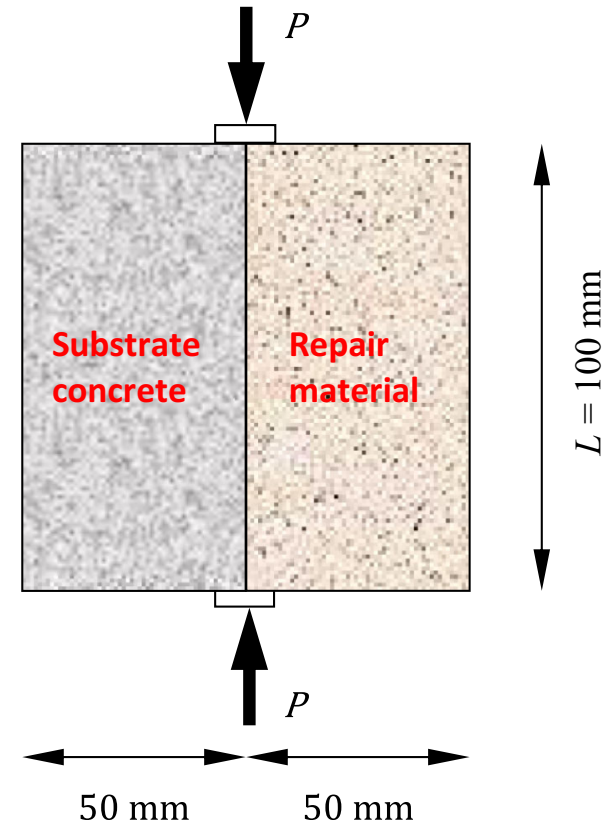

Fig. 1 Tensile cube split test

where, $\sigma_{y \text { max }}$ is the maximum local vertical compressive stress at the centre of the composite cube (MPa); $\sigma_{x \text { max }}$ is the maximum horizontal tensile stress at the bonded interface of the composite cube (MPa); $P$ is the compressive load on the cube $(\mathrm{N}) ; L$ is the height of the composite cube ( $\mathrm{mm}$ ).

Equation 2 is used to calculate the tensile splitting strength (bond strength), $\sigma_{x} \max$, at the maximum (failure) load, $P$.

\subsubsection{Compression test}

The compressive strength of both the repair material and substrate prisms $(100 \times 100 \times 50 \mathrm{~mm})$, which separated after the tensile split test, was determined. The crushing load was applied in the same direction as the splitting test.

\section{Results and discussion}

\subsection{Microwave curing temperature}

The top surface temperature of each cube was monitored with a Flir i7 thermal camera at regular intervals during $45 \mathrm{~min}$ of microwave curing. The temperatures at the centre of the surface are plotted in
Fig. 2 for four "repaired" cubes of a repair material. Typical temperature variation between the four specimens was up to $12 \%$. This is due to the surface temperature variations which have been reported elsewhere $[24,25]$ and also due to the location of each of the four cubes within the microwave oven. The average temperature of the four cubes per each repair material is used in future discussion.

\subsection{Type of bond failure}

All failures for both normally and microwave cured samples of all Series (1-4, Table 1) occurred at the bonded interface between the substrate and the repair material. A typical example of the two halves obtained after the splitting test is shown in Fig. 3. This yielded visually undamaged interface surfaces between the substrate and repair halves of each cube.

\subsection{Effect of microwave curing on bond strength}

Details of all bond strength results are shown in Table 3 and Fig. 4. The bond strengths are the average of four composite cube specimens per repair material.

\subsubsection{Bond strength at "repair temperatures" 20, 10 and $2{ }^{\circ} \mathrm{C}$}

The graphs in Fig. 4 and their corresponding data in Table 3 show that microwave curing applied under "repair temperatures" of 20,10 and $2{ }^{\circ} \mathrm{C}$ did not significantly affect the repair/substrate interfacial bond strength (Series 1, 2 and 3 tests) at 28 days age compared with the normal cured specimens. Table 3 shows that eleven of the twelve mixes of Series 1, 2 and 3 show an increase of +10 to $-11 \%$ giving an average increase of $0.5 \%$. The remaining mix (Series 3 , Material 3) shows a decrease of $21 \%$ which is
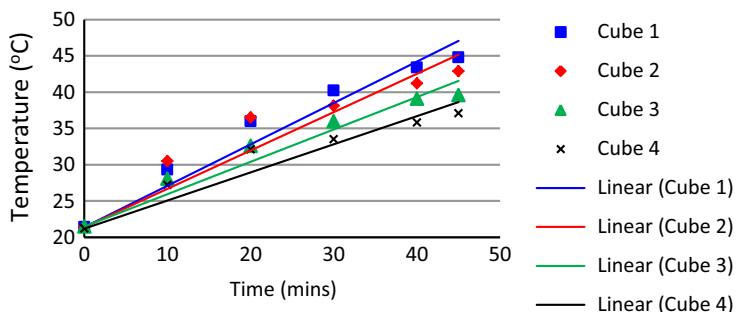

Fig. 2 Typical time-temperature graph for microwave cured CEM II Mortar (repair applied at $20^{\circ} \mathrm{C}$ ) 


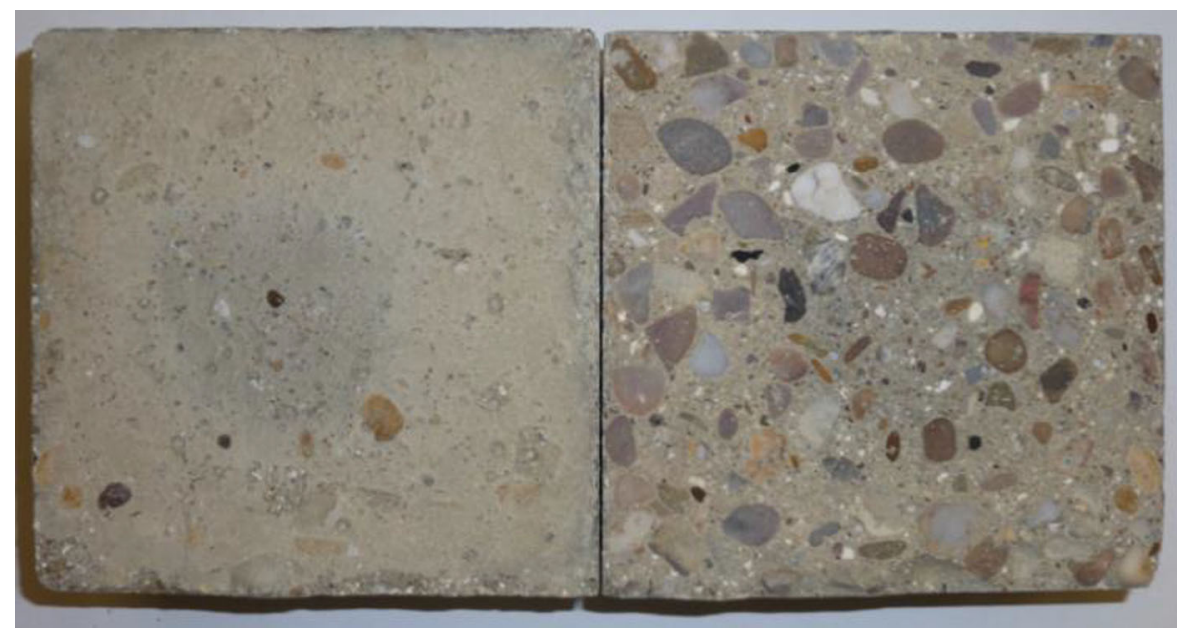

Fig. 3 Typical failure at the bonded interface between substrate and repair material

Table 3 Bond strength results

\begin{tabular}{|c|c|c|c|c|c|c|c|c|}
\hline Series & $\begin{array}{l}\text { Repair } \\
\text { temperature } \\
\left({ }^{\circ} \mathrm{C}\right)\end{array}$ & $\begin{array}{l}\text { Repair } \\
\text { material }\end{array}$ & $\begin{array}{l}\text { Bond strength } \\
\text { normal curing } \\
(\mathrm{MPa})^{\mathrm{a}}\end{array}$ & $\begin{array}{l}\text { SD } \\
(\mathrm{MPa})^{\mathrm{b}}\end{array}$ & $\begin{array}{l}\text { Bond strength } \\
\text { microwave curing } \\
(\mathrm{MPa})^{\mathrm{a}}\end{array}$ & $\begin{array}{l}\mathrm{SD} \\
(\mathrm{MPa})^{\mathrm{b}}\end{array}$ & $\begin{array}{l}\text { Microwave } \\
\text { curing } \\
\text { temperature }\left({ }^{\circ} \mathrm{C}\right)^{\mathrm{c}}\end{array}$ & $\begin{array}{l}\text { Bond } \\
\text { strength } \\
\text { increase }(\%)\end{array}$ \\
\hline \multirow[t]{4}{*}{1} & 20 & Material 1 & 2.30 & 0.15 & 2.50 & 0.28 & 39.6 & 9 \\
\hline & 20 & Material 2 & 2.25 & 0.33 & 2.15 & 0.27 & 47.4 & -4 \\
\hline & 20 & Material 3 & 2.55 & 0.44 & 2.75 & 0.42 & 45.8 & 8 \\
\hline & 20 & Material 4 & 1.40 & 0.25 & 1.40 & 0.16 & 41.1 & 0 \\
\hline \multirow[t]{4}{*}{2} & 10 & Material 1 & 1.95 & 0.34 & 2.15 & 0.21 & 37.9 & 10 \\
\hline & 10 & Material 2 & 2.05 & 0.16 & 1.90 & 0.22 & 42.7 & -7 \\
\hline & 10 & Material 3 & 2.30 & 0.51 & 2.25 & 0.16 & 41.0 & -2 \\
\hline & 10 & Material 4 & 1.85 & 0.22 & 1.65 & 0.12 & 38.9 & -11 \\
\hline \multirow[t]{4}{*}{3} & 2 & Material 1 & 2.15 & 0.17 & 2.15 & 0.01 & 35.9 & 0 \\
\hline & 2 & Material 2 & 2.65 & 0.20 & 2.70 & 0.18 & 40.0 & 2 \\
\hline & 2 & Material 3 & 2.60 & 0.26 & 2.10 & 0.07 & 40.0 & -21 \\
\hline & 2 & Material 4 & 1.90 & 0.30 & 1.90 & 0.07 & 40.9 & 0 \\
\hline \multirow[t]{4}{*}{4} & -5 & Material 1 & 0.75 & 0.19 & 2.45 & 0.31 & 34.6 & 227 \\
\hline & -5 & Material 2 & 0.70 & 0.13 & 1.30 & 0.17 & 38.7 & 86 \\
\hline & -5 & Material 3 & 0.80 & 0.18 & 1.95 & 0.34 & 37.6 & 143 \\
\hline & -5 & Material 4 & 1.15 & 0.24 & 2.15 & 0.28 & 38.2 & 87 \\
\hline
\end{tabular}

\footnotetext{
a 28 day strength

b Standard deviation

c Average (of 4 cubes) top surface middle point temperature of repaired cubes at the end of microwave curing
}

inconsistent with the trends observed for this material in Series 1, 2 and 4.

The bond strengths of the normal and microwave cured commercial Repair Materials 1, 2 and 3 ranged between 2.15 and $2.75 \mathrm{MPa}$ for the "repair temperature" of $20^{\circ} \mathrm{C}$. The corresponding ranges for 10 and $2{ }^{\circ} \mathrm{C}$ "repair temperatures" are 1.9-2.3 MPa and 2.1-2.70 MPa respectively. These bond strength ranges are fairly similar but correspond to repair materials whose compressive strengths vary greatly 


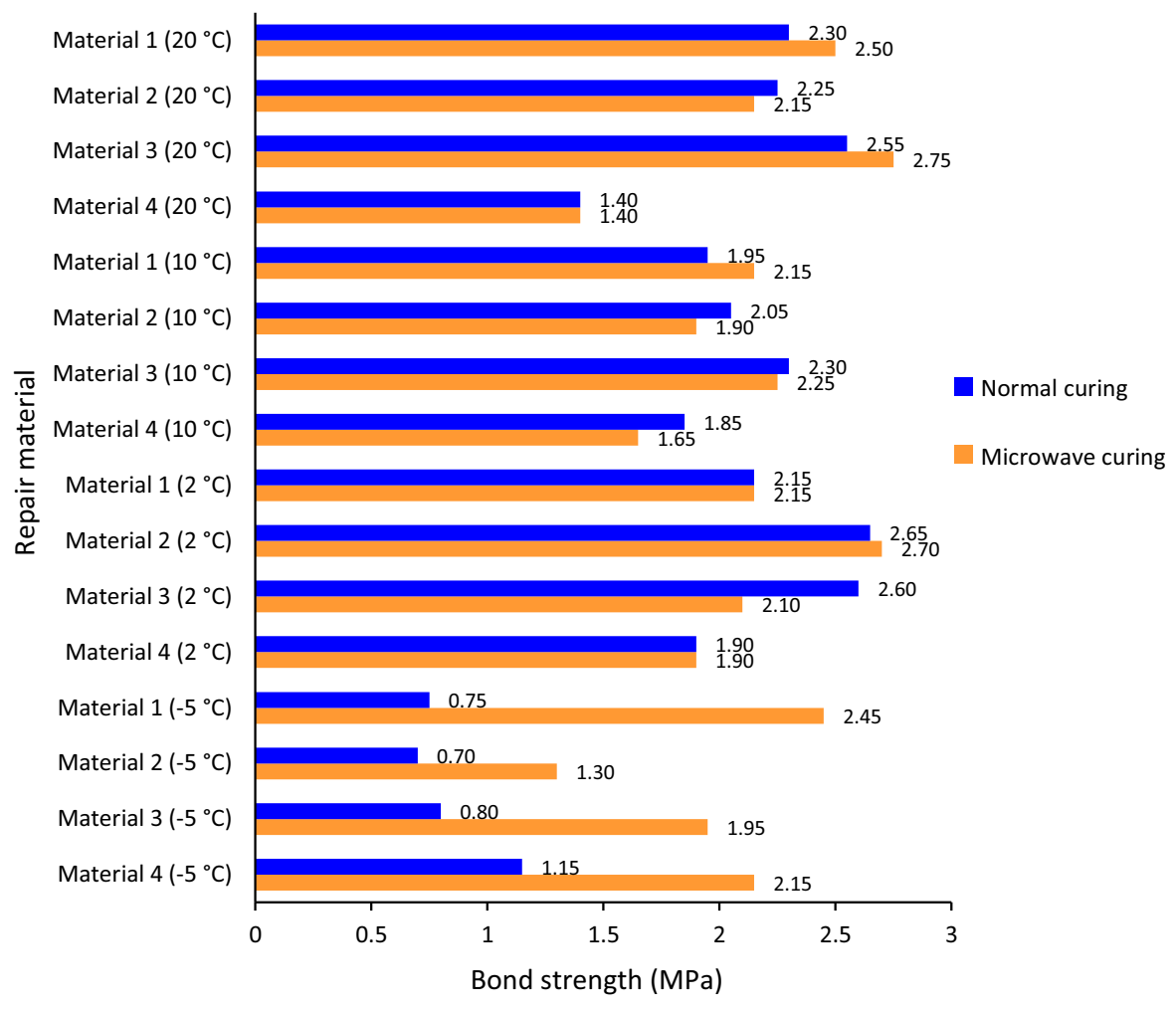

Fig. 4 Comparison graph of average bond strength for Series 1, 2, 3 and 4 tests

between 21 and $67 \mathrm{MPa}$ (Table 5). A comparison of the above range of bond strengths with the classification of concrete overlays provided by Sprinkel and Ozyildirin in Table 4 [29] shows that they mostly fall within the "excellent" range for both normally and microwave cured specimens.

The tensile bond strength of the normally and microwave cured CEM II Mortar (Material 4) with the substrate ranges between 1.4 and $1.9 \mathrm{MPa}$ for the "repair temperatures" of 20, 10 and $2{ }^{\circ} \mathrm{C}$ (Fig. 4). These are consistently and significantly lower than the bond strengths developed by the commercial Repair

Table 4 Bond strength classification provided by Sprinkel and Ozyildirim [29]

\begin{tabular}{ll}
\hline Bond strength (MPa) & Classification \\
\hline $0-0.7$ & Poor \\
$0.7-1.4$ & Fair \\
$1.4-1.7$ & Good \\
$1.7-2.1$ & Very good \\
$\geq 2.1$ & Excellent \\
\hline
\end{tabular}

Materials 1, 2 and 3 at these temperatures (1.9-2.75 MPa).

\subsubsection{Bond strength at "repair temperature" $-5^{\circ} \mathrm{C}$}

Figure 4 shows that 45 min of microwave curing applied under the "repair temperature" of $-5{ }^{\circ} \mathrm{C}$ (Series 4 tests) produced significantly higher bond strengths than normal curing at $-5{ }^{\circ} \mathrm{C}$ for all repair mortars. The normal cured repairs suffered very considerable loss of bond due to early age freezing. Repair Material 1 and the CEM II Mortar performed particularly well with their microwave cured bond strengths being similar to the values achieved at "repair temperatures" of 20,10 and $2{ }^{\circ} \mathrm{C}$. In fact the microwave cured CEM II Mortar applied at $-5{ }^{\circ} \mathrm{C}$ has a higher bond strength $(2.15 \mathrm{MPa})$ than the CEM II Mortar applied at 20,10 and $2{ }^{\circ} \mathrm{C}$ (1.4-1.9 MPa). A comparison with the classification provided in Table 4 shows that with the exception of Repair Material 2 all other microwave cured materials fall within the "very good" and "excellent" category of bond strength. The corresponding normally cured materials were in the "fair" category. 
The bond strength of the microwave cured Repair Material 2, applied at $-5{ }^{\circ} \mathrm{C}$, is significantly lower than its bond strength when applied at 20,10 and $2{ }^{\circ} \mathrm{C}$. The bond strength of microwave cured Material 2 decreased from the range (1.9-2.7 MPa) to $1.3 \mathrm{MPa}$ under $-5{ }^{\circ} \mathrm{C}$ repair application.

\subsection{Effect of microwave curing on prism compressive strength}

The strengths of the $100 \times 100 \times 50 \mathrm{~mm}$ prisms of repair mortars are shown in Table 5 and Fig. 5. The compressive strength of the $100 \times 100 \times 50 \mathrm{~mm}$ prism test specimens is less than the cube crushing strength due to the size effect and height/width ratio of the sample. The two are comparable if correction factors are applied [5]. The correction factor is influenced by the strength, size and shape of the test specimen. However, the aim of this investigation was to study the effect of microwave curing relative to normal curing rather than evaluating the absolute cube strength.
The variation in 28 day compressive strength of microwave cured repairs applied under "repair temperatures" of 20,10 and $2{ }^{\circ} \mathrm{C}$, relative to normal curing, ranged between +7 and $-18 \%$ (Table 5). The variation was fairly randomly distributed for each of the four repair materials. The average was a reduction in strength of microwave cured specimens relative to normal curing of $6.75 \%$ for the twelve mixes of series 1,2 and 3, which is similar to other reported results [14]. This reduction may be due to the short period of high temperature curing at early age provided by microwave exposure, similar to the effect of high temperature curing by conventional methods on the long term strength of concrete. Concrete develops less dense products of hydration under higher temperature curing, leading to lower long term strength [5]. However, the average reduction of $6.75 \%$ under microwave curing is less than the typical reduction in 28 day strength of $10-15 \%$ observed under steam curing [8] and 10-20\% reduction observed with the hot-mix method when either the constituents are heated prior to mixing or steam is injected in the

Table 5 Compressive strength of Series 1, 2, 3 and 4 prisms of repair mortars

\begin{tabular}{|c|c|c|c|c|c|c|c|c|}
\hline Series & $\begin{array}{l}\text { Repair } \\
\text { temperature } \\
\left({ }^{\circ} \mathrm{C}\right)\end{array}$ & $\begin{array}{l}\text { Repair } \\
\text { material }\end{array}$ & $\begin{array}{l}\text { Prism strength } \\
\text { normal curing } \\
(\mathrm{MPa})^{\mathrm{a}}\end{array}$ & $\begin{array}{l}\mathrm{SD} \\
(\mathrm{MPa})^{\mathrm{b}}\end{array}$ & $\begin{array}{l}\text { Prism strength } \\
\text { microwave curing } \\
(\mathrm{MPa})^{\mathrm{a}}\end{array}$ & $\begin{array}{l}\text { SD } \\
(\mathrm{MPa})^{\mathrm{b}}\end{array}$ & $\begin{array}{l}\text { Microwave } \\
\text { curing } \\
\text { temperature }\left({ }^{\circ} \mathrm{C}\right)^{\mathrm{c}}\end{array}$ & $\begin{array}{l}\text { Prism } \\
\text { strength } \\
\text { increase }(\%)\end{array}$ \\
\hline \multirow[t]{4}{*}{1} & 20 & Material 1 & 51.5 & 2.34 & 55.0 & 3.57 & 39.6 & 7 \\
\hline & 20 & Material 2 & 25.0 & 3.10 & 21.0 & 2.97 & 47.4 & -16 \\
\hline & 20 & Material 3 & 66.0 & 4.05 & 54.0 & 3.47 & 45.8 & -18 \\
\hline & 20 & Material 4 & 42.0 & 1.84 & 38.5 & 5.21 & 41.1 & -8 \\
\hline \multirow[t]{4}{*}{2} & 10 & Material 1 & 61.0 & 1.56 & 57.5 & 5.71 & 37.9 & -6 \\
\hline & 10 & Material 2 & 28.0 & 4.47 & 26.5 & 1.68 & 42.7 & -5 \\
\hline & 10 & Material 3 & 67.0 & 6.10 & 57.0 & 2.22 & 41.0 & -15 \\
\hline & 10 & Material 4 & 38.0 & 2.48 & 38.5 & 2.84 & 38.9 & 1 \\
\hline \multirow[t]{4}{*}{3} & 2 & Material 1 & 63.0 & 6.90 & 64.5 & 2.36 & 35.9 & 2 \\
\hline & 2 & Material 2 & 31.5 & 2.16 & 28.0 & 2.79 & 40.0 & -11 \\
\hline & 2 & Material 3 & 59.0 & 8.86 & 58.5 & 6.65 & 40.0 & 0 \\
\hline & 2 & Material 4 & 42.5 & 3.39 & 37.5 & 4.46 & 40.9 & -12 \\
\hline \multirow[t]{4}{*}{4} & -5 & Material 1 & 34.0 & 2.23 & 49.0 & 5.08 & 34.6 & 44 \\
\hline & -5 & Material 2 & 21.5 & 3.28 & 24.0 & 3.37 & 38.7 & 12 \\
\hline & -5 & Material 3 & 21.5 & 2.01 & 50.0 & 4.54 & 37.6 & 133 \\
\hline & -5 & Material 4 & 31.0 & 6.11 & 32.0 & 2.41 & 38.2 & 3 \\
\hline
\end{tabular}

\footnotetext{
a 28 day prism strength

b Standard deviation

c Average (of 4 cubes) top surface middle point temperature of repaired cubes at the end of microwave curing
} 


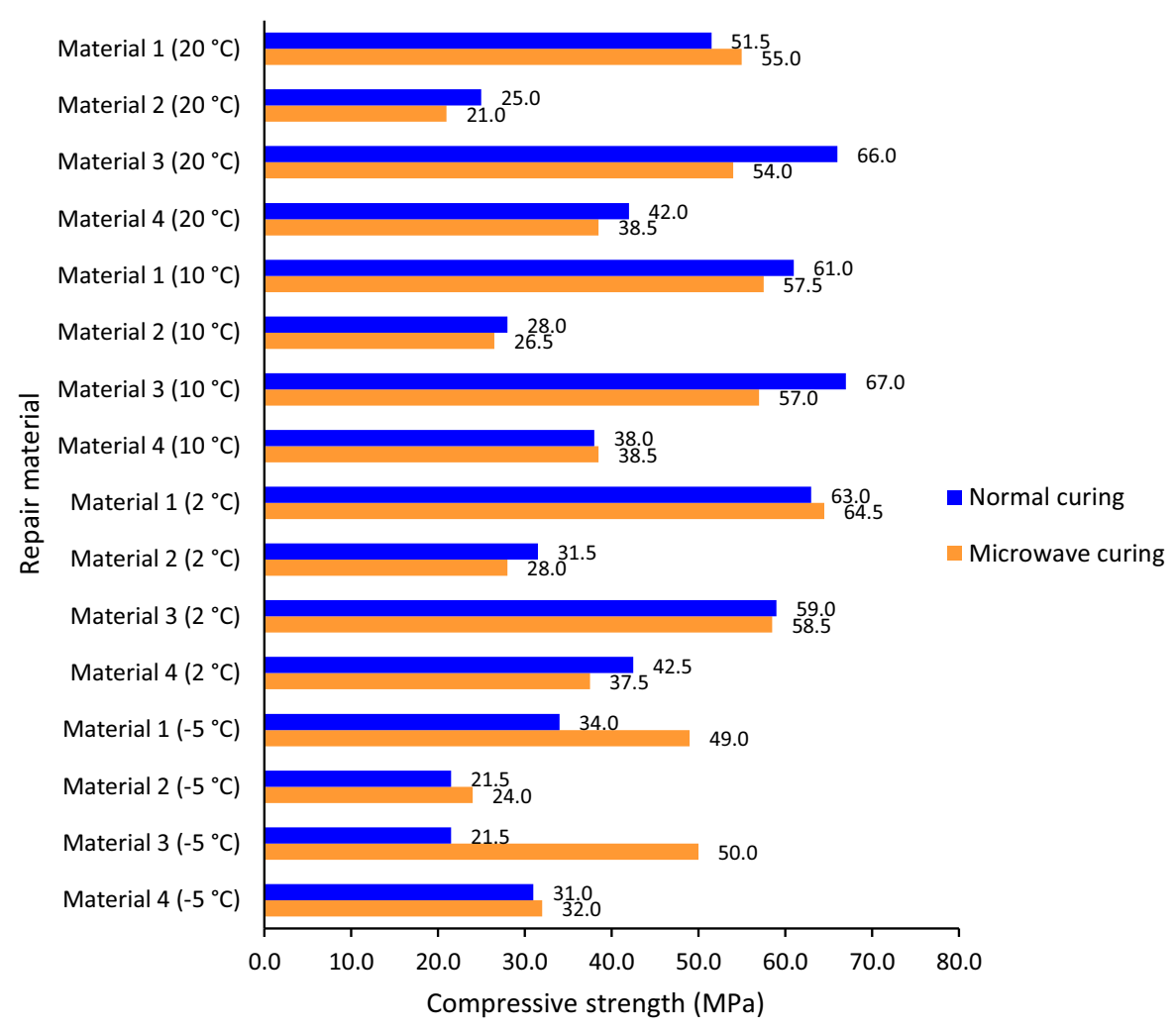

Fig. 5 Comparison graph of prism compressive strength for Series 1, 2, 3 and 4 tests

mixer [5]. The lower reduction in long term strength with microwave curing may be due to lower temperature of curing (about $40{ }^{\circ} \mathrm{C}$ ) and, therefore, denser hydration products compared with curing temperatures of $60-70{ }^{\circ} \mathrm{C}$ produced in concrete by steam curing and heating of mix constituents. Porosity and pore structure of microwave cured concrete is also being investigated by the authors' ongoing research, to determine its relationship with strength.

Microwave curing provided significantly higher compressive strength than normal curing for repairs applied at $-5{ }^{\circ} \mathrm{C}$. The increase was 12,44 and $133 \%$ for 3 out of 4 repair materials. The CEM II Mortar (Material 4) showed a modest increase of $3 \%$. However, the 28 day compressive strength of repairs applied at $-5{ }^{\circ} \mathrm{C}$ was less than the repairs applied under higher "repair temperatures" of $2-20{ }^{\circ} \mathrm{C}$, thereby indicating some effect of freezing. For example, the strength of microwave cured Material 1 decreased from the range (55-64.5) $\mathrm{MPa}$ to $49 \mathrm{MPa}$. The corresponding reductions for Repair Material 3 and CEMII Mortar were (54-58.5) MPa to $50 \mathrm{MPa}$ and (37.5-38.5) $\mathrm{MPa}$ to $32 \mathrm{MPa}$ respectively. Repair Material 2 shows insignificant reduction in compressive strength from (21-28) MPa to $24 \mathrm{MPa}$. Material 2 has a lower density of $1730 \mathrm{~kg} / \mathrm{m}^{3}$ than Materials 1,3 and 4 and higher resistance to freezing. The role of the admixtures in the proprietary Repair Material 2 on the bond and compressive strength under microwave curing needs further research.

$45 \mathrm{~min}$ of microwave curing to a temperature of about $40{ }^{\circ} \mathrm{C}$ of repairs applied at sub-zero ambient temperature have resulted in higher bond and compressive strength than the strength of control specimens which were not exposed to microwave curing. Microwave curing was applied to the fresh repair after $30 \mathrm{~min}$ of application. The increase in strength is due to the heat provided to early age repair by microwave curing. It is known that curing temperature of concrete before it is exposed to frost attack at an early age has a significant effect on its longer term strength [5]. Early age heating by microwave curing has accelerated the hydration of cement, resulting in a reduced amount of water available for freezing in the pore structure. It has also provided 
sufficient strength to the matrix to withstand subsequent exposure to freezing during $24 \mathrm{~h}$ of sub-zero temperature. According to ACI 306R- 10 [6] on cold weather concreting, if concrete is able to achieve sufficient strength (approximately 3.5 MPa), it will resist damage caused by one cycle of freezing and thawing.

The effects of frost attack are not relevant for repair application above freezing temperatures and the effects of high temperature curing by microwaves become predominant. Early age strength increases as curing temperature increases, due to accelerated hydration, but with some loss of long-term strength. The reduction in long term strength is higher with increasing curing temperature.

\subsection{Relationship between bond strength and compressive strength}

The graphs of bond strength versus compressive strength of the $100 \times 100 \times 50 \mathrm{~mm}$ prisms are shown in Figs. 6a-b for repair materials applied at $20,10,2{ }^{\circ} \mathrm{C}$ and at $-5{ }^{\circ} \mathrm{C}$ respectively. No relationship between bond strength and compressive strength is observed for both normally and microwave cured repairs applied at "repair temperatures" of 20,10 and
$2{ }^{\circ} \mathrm{C}$ (Series 1, 2 and 3 tests, Fig. 6a). The bond strength of the commercial Repair Materials 1, 2 and 3 remains reasonably constant at (1.90-2.75) $\mathrm{MPa}$ for the wide range of prism strengths (21-67) MPa. This is because repair materials are specially formulated by the manufacturers to provide maximum bond strength while tailoring the compressive strength to specific applications for different classes of repair materials given in BS EN 1504-3 [30]. The bond strength of the CEM II Mortar (Material 4), for both normal and microwave curing, falls significantly below the data of the other repair materials in Fig. 6a.

The graphs for "repair temperature" of $-5{ }^{\circ} \mathrm{C}$, in Fig. $6 \mathrm{~b}$, show that under microwave curing, three of the four repair materials (Material 1, 3 and CEM II mortar, Table 3) develop bond strengths between 1.95 and 2.45 MPa while their compressive strength ranges between 32 and $50 \mathrm{MPa}$. The other microwave cured repair material (Material 2) develops a lower bond strength of $1.3 \mathrm{MPa}$ at $-5{ }^{\circ} \mathrm{C}$ of repair application. The corresponding bond strengths of the normally cured Repair Materials 1, 2 and 3 for "repair" temperature of $-5{ }^{\circ} \mathrm{C}$ fall in the significantly lower range of $0.7-0.8 \mathrm{MPa}$ while their compressive strength ranges between 21.5 and $34 \mathrm{MPa}$. The
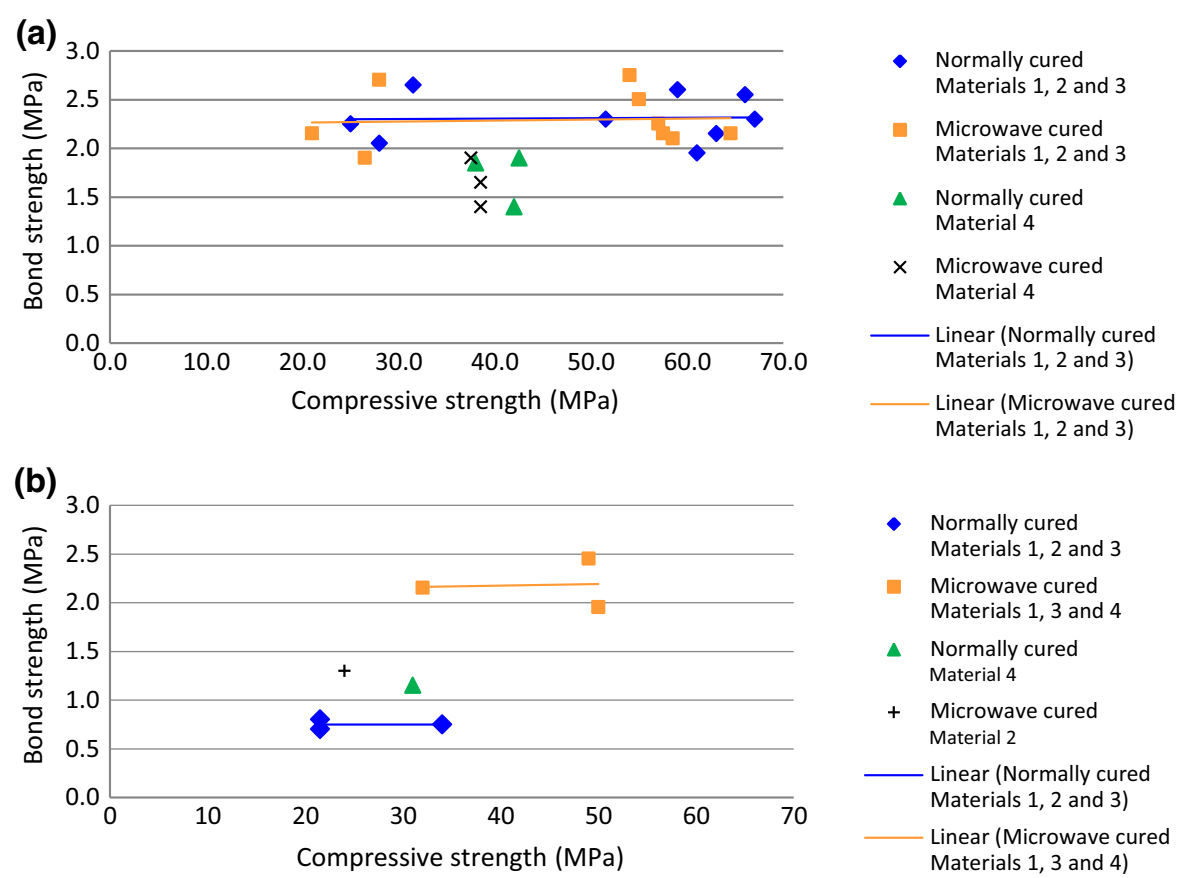

Fig. 6 Bond strength versus prism compressive strength for (a) Series 1, 2 and 3 ("repair temperatures" 2-20 ${ }^{\circ} \mathrm{C}$ ) and (b) Series 4 ("repair temperature" $-5{ }^{\circ} \mathrm{C}$ ) 
normally cured CEM II Mortar (Material 4) also falls in the low range bond strength of $1.15 \mathrm{MPa}$ with a compressive strength of $31 \mathrm{MPa}$.

\subsection{Effect of microwave exposure on strength of substrate concrete}

Exposure of the hardened substrate concrete prisms to microwave power during the curing of the repair patch (132 Watts for $45 \mathrm{~min}$ ) did not affect its compressive strength. The difference between the compressive strength of microwave and normally cured prism halves of the substrate varied between 11 and $-11 \%$.

\subsection{Extrapolation of the results to the field}

The extrapolation of the results to the field will primarily be concerned with the power required to produce on site the same target temperature of microwave curing as achieved in the laboratory, under the actual ambient conditions and repair patch properties encountered on site. This aspect has been addressed by developing an analytical approach and a Fixed Time Power Regulating (FTPR) algorithm for the control system of the microwave curing prototype developed in the MCure project. An analytical expression to estimate the microwave curing power required for a patch repair has also been derived by the authors [25]. The MCure prototype has been successfully used in field trials to microwave cure repair patches $1 \mathrm{~m} \times 1 \mathrm{~m} \times 64 \mathrm{~mm}$ thick [31]. The next stage of development of the MCure prototype will be an industrial mobile system.

The maximum microwave curing temperature of a repair patch should not exceed the recommended $40-45{ }^{\circ} \mathrm{C}$ value $[24,25]$. Consequently, at higher ambient temperature, the temperature differential $\Delta T$ available for microwave heating is reduced. The long term reduction in strength will depend on the maximum curing temperature, not on the ambient. The reduction of long term strength with high temperature curing is recognised in concrete practice [5], although it is less pronounced with microwave curing.

\section{Conclusions}

The following conclusions are based on the results presented in this paper on repairs applied under ambient temperatures 20,10 and $2{ }^{\circ} \mathrm{C}$ and microwave cured for $45 \mathrm{~min}$ immediately after repair application.

- Microwave curing of the fresh repair has no negative effect on the repair/substrate interfacial bond strength at 28 days age. In many cases, the bond strength of the microwave cured repair is slightly higher than normally cured repair.

- The bond strengths of the normally and microwave cured commercial Repair Materials (1, 2 and 3) are similar for the "repair temperatures" of 20,10 and $2{ }^{\circ} \mathrm{C}$. The values range between 1.9 and $2.75 \mathrm{MPa}$. The bond strengths of the CEM II repair mortar are lower (1.4-1.9 MPa).

- The compressive strengths of the repair materials bear no relationship with their bond strength with the substrate. The bond strengths of the normal and microwave cured Repair Materials 1, 2 and 3 are between 1.9 and $2.75 \mathrm{MPa}$ for the wide range of compressive strengths (21-67) MPa.

- Microwave curing to about $40{ }^{\circ} \mathrm{C}$ reduces the 28 day compressive strength relative to the normally cured repair materials by an average of $6.75 \%$.

- Microwave exposure of the substrate during curing of the repair has no adverse effect on its compressive strength.

The following conclusions apply to microwave curing of repairs applied at $-5{ }^{\circ} \mathrm{C}$.

- A short period of microwave curing of the fresh repair followed by sub-zero temperature exposure provides significantly higher bond strength at 28 days compared to control samples exposed to normal curing at $-5{ }^{\circ} \mathrm{C}$.

- Microwave cured commercial Repair Materials 1, 3 and 4 (CEM II Repair Mortar) perform particularly well under freezing conditions. Microwave cured Repair Material 1 applied at $-5{ }^{\circ} \mathrm{C}$ has a bond strength of $2.45 \mathrm{MPa}$ compared with (2.15-2.5) $\mathrm{MPa}$ for repairs applied at $20-2{ }^{\circ} \mathrm{C}$. The corresponding values for Material 3 are 1.95 MPa compared with 2.1-2.75 MPa. Microwave cured CEM II Mortar applied at $-5{ }^{\circ} \mathrm{C}$ develops a bond strength of $2.15 \mathrm{MPa}$ compared with (1.4-1.75) $\mathrm{MPa}$ for repair application at $\left(20-2{ }^{\circ} \mathrm{C}\right)$. These bond strengths of microwave cured repairs compare favourably with the 
"excellent" classification given to bond exceeding $2.1 \mathrm{MPa}$ [29].

- The normally (non-microwave) cured repair materials applied at a "repair temperature" of $-5{ }^{\circ} \mathrm{C}$ suffer frost attack which results in bond strengths below 1.15 MPa.

- Microwave curing provides higher 28 days compressive strength than normal curing for repairs "applied" at $-5{ }^{\circ} \mathrm{C}$. The difference is very high for Repair Materials 1 and 3 and fairly insignificant for Materials 2 and 4 (CEM II Mortar), indicating severity of frost attack on materials 2 and 4 .

- The 28 day compressive strength of microwave cured repair materials applied at $-5{ }^{\circ} \mathrm{C}$ is about $20 \%$ lower than the corresponding materials applied at $\left(20-2{ }^{\circ} \mathrm{C}\right)$, thereby showing some effect of damage due to freezing.

- The compressive strengths of the repair materials bear no relationship with their tensile bond strength with the substrate. The bond strengths of the microwave cured materials are between 1.95 and $2.45 \mathrm{MPa}$ for the compressive strength range of (32-50) MPa. The corresponding bond strengths of normally cured materials are $0.7-1.15 \mathrm{MPa}$ against a compressive strength range of 21.5-34 MPa.

Acknowledgements The authors gratefully acknowledge the European Commission 7th Framework Programme for financing this research for the MCure Project (Grant No: 605664 ) which has developed a prototype for microwave curing of concrete repair.

Open Access This article is distributed under the terms of the Creative Commons Attribution 4.0 International License (http:// creativecommons.org/licenses/by/4.0/), which permits unrestricted use, distribution, and reproduction in any medium, provided you give appropriate credit to the original author(s) and the source, provide a link to the Creative Commons license, and indicate if changes were made.

\section{References}

1. Plum D (1991) Materials—what to specify. Int J Constr Maint Repair 5(4):3-7

2. Emmons PH (1992) Concrete repair maintenance illustrated, 1st edn. Willey, New York

3. The Concrete Society (1991) Patch repair of reinforced concrete. Model specification and method of measurement. Technical Report no 38
4. Leung CKY, Pheeraphan T (1995) Microwave curing of Portland cement concrete: experimental results and feasibility for practical application. Constr Build Mater 9:67-73. doi:10.1016/0950-0618(94)00001-I

5. Neville AM (2011) Properties of concrete, 5th edn. Pearson Education Limited, Harlow

6. ACI 306R-10 (2010) Guide to cold weather concreting. American Concrete Institute, Committee 306, Detroit, Michigan

7. Ong KCG, Akbarnezhad A (2014) Microwave-assisted concrete technology: production, demolition and recycling, 1st edn. CRC Press, Taylor \& Francis Group, Boca Raton

8. Wu X, Dong J, Tang M (1987) Microwave curing technique in concrete manufacture. Cem Concr Res 17:205-210. doi:10.1016/0008-8846(87)90103-7

9. Hutchison RG, Chang JT, Jennings HM, Brodwin ME (1991) Thermal acceleration of Portland cement mortars with microwave energy. Cem Concr Res 21:795-799. doi:10.1016/0008-8846(91)90174-G

10. Leung CKY, Pheeraphan T (1995) Very high early strength of microwave cured concrete. Cem Concr Res 25:136-146. doi:10.1016/0008-8846(94)00121-E

11. Leung CKY, Pheeraphan T (1997) Determination of optimal process for microwave curing of concrete. Cem Concr Res 27:463-472. doi:10.1016/S0008-8846(97)00015-X

12. Sohn D, Johnson DL (1999) Microwave curing effects on the 28-day strength of cementitious materials. Cem Concr Res 29:241-247. doi:10.1016/S0008-8846(98)00189-6

13. Lee MG (2007) Preliminary study for strength and freezethaw durability of microwave and steam-cured concrete. J Mat Civ Eng 11:972-976. doi:10.1061/(ASCE)08991561(2007)19:11(972)

14. Rattanadecho P, Suwannapum N, Chatveera B, Atong D, Makul N (2008) Development of compressive strength of cement paste under accelerated curing by using a continuous microwave thermal processor. Mat Sci Eng A 472:299-307. doi:10.1016/j.msea.2007.03.035

15. Makul N, Agrawal DK (2011) Influence of microwave-accelerated curing procedures on the microstructure and strength characteristics of Type I-Portland cement pastes. J Ceram Process Res 12:376-381

16. Makul N, Rattanadecho P, Agrawal DK (2014) Application of microwave energy in cement and concrete-A review. Ren Sustain Energy Rev 37:715-733. doi:10.1016/j.res.2014.05. 054

17. Prommas R, Rungsakthaweekul T (2014) Effect of microwave curing conditions on high strength concrete properties. In: Proceedings of the 11th eco-energy and materials science and engineering symposium-energy procedia 56:26-34. doi:10.1016/j.egypro.2014.07.128

18. Tilly G, Jacobs J (2007) Concrete repairs: observations on performance in service and current practice, CONREPNET Project Report, IHS BRE Press, Watford

19. Matthews S (2007) CONREPNET: performance-based approach to the remediation of reinforced concrete structures: achieving durable repaired concrete structures. J Build Apprais 3(1):6-20. doi:10.1057/palgrave.jba. 2950063

20. BS EN 197-1 (2011) Cement-Part 1: composition, specifications and conformity criteria for common cements. BSI, London 
21. ASTM F1317-98 (1998) Standard test method for calibration of microwave ovens. ASTM International, West Conshohocken

22. BS EN 60705 (2012) Household microwave ovens. Methods for measuring performance. BSI, London

23. Building Research Establishment (1998) Design of normal concrete mixes, 2nd edn. Building Research Establishment, Watford

24. Mangat P.S, Grigoriadis K, Abubakri S (2015) Microwave curing of concrete bridge repairs. In: Proceedings of the 16th European Bridge Conference, Edinburgh

25. Mangat P.S, Grigoriadis K, Abubakri S (2016) Microwave curing parameters of in situ concrete repairs. Constr Build Mater 112:856-866. doi:10.1016/j.conbuildmat.2016.03. 007

26. BS EN 12390-6 (2009) Testing hardened concrete-Part 6: Tensile splitting strength of test specimens. BSI, London

27. Nilsson S (1961) The tensile strength of concrete determined by splitting tests on cubes. RILEM Bul 11:63-67
28. Carmona S, Aguado A (2012) New model for the indirect determination of the tensile stress-strain curve of concrete by means of the Brazilian test. Mat Struct 45:1473-1485. doi:10.1617/S11527-012-9851-0

29. Sprinkel M, Ozyildirim C (2000) Evaluation of high performance concrete overlays placed on route 60 over Lynnhaven inlet in Virginia. Final Report VTRC 01-R1. Virginia Transport Research Council. Charlottesville, USA

30. BS EN 1504-3 (2005) Products and systems for the protection and repair of concrete structures-Definitions, requirements, quality control and evaluation of conformityPart 3: Structural and non-structural repair. BSI, London

31. Mangat P.S, Grigoriadis K, Abubakri S, Javaid A, Zhao C (2016) Microwave system for in-situ curing of concrete repair. In: Proceedings of the 6th international conference on concrete repair, Thessaloniki, Greece, vol 1, pp 267-272 